\title{
Pengembangan Media Virtual Reality Pada Muatan Pelajaran IPA Kelas VI Sekolah Dasar
}

\author{
Mardiki Supriadi ${ }^{1}$, L. Virginayoga Hignasari ${ }^{2}$
}

\section{Info Artikel}

Sejarah Artikel:

Diterima: Oktober 2019

Direvisi: Nopember 2019

Dipublikasikan: Des 2019

e-ISSN: 2620-3081

p-ISSN: 1411-2744

DOI: https://doi.org/ 10.21009/jtp.v21i3.13025

\begin{abstract}
The media is based virtual reality, wich can help educators as learning media explain sciene subject matter in learning activities. The purpose of this study is to produce a virtual reality-based learning media in science class IV elementary school subjects. This research is a development research with $4 D$ development model from Thiagarajan which has been supported. This development model consists of definition, definition, design (design), development (development). The research and development stage is carried out until development. The results showed that virtual reality media is very feasible to be used in class VI of elementary schools on the subject of natural sciences with support for the results of expert validation. The results of validation by media experts are $85 \%$ or Very Valid. Material expert validation on the media consisted of 5 aspects. The results of validation by material experts are $82 \%$ or Very Valid. The validation of field application experts to the developed media consisted of 3 aspects. The results of validation by the field application experts are $89 \%$ or Very Valid.
\end{abstract}

Keywords: learning media, virtual reality, science learning content, elementary school

Abstrak: Media berbasis virtual reality dapat membantu pendidik sebagai media pembelajaran untuk menjelaskan materi muatan pelajaran IPA dalam kegiatan pembalajaran. Tujuan penelitian ini adalah menghasilkan sebuah media pembelajaran berbasis virtual reality pada muatan pelajaran IPA kelas IV sekolah dasar. Penelitian ini merupakan penelitian pengembangan dengan model pengembangan $4 D$ dari Thiagarajan yang telah dimodifikasi. Model pengembangan ini terdiri atas tahap define (pendefinisian), design (perancangan), develop (pengembangan). Tahap penelitian dan pengembangan dilaksanakan sampai tahap develop (pengembangan). Hasil penelitian menujukkan bahwa media virtual reality sangat layak untuk digunakan di kelas VI sekolah dasar pada matan pelajaran IPA dengan merujuk pada hasil validasi para ahli. Hasil validasi oleh ahli media yakni $85 \%$ atau Sangat Valid. Validasi ahli materi pada media terdiri dari 5 aspek. Hasil validasi oleh ahli materi yakni $82 \%$ atau Sangat Valid. Validasi ahli penerapan lapangan terhadap media yang dikembangkan terdiri dari 3 aspek. Hasil validasi oleh ahli penerapan lapangan yakni 89\% atau Sangat Validar.

Kata kunci: media pembelajaran, virtual reality, muatan pelajaran IPA, sekolah dasar

\footnotetext{
${ }^{1}$ Universitas Mahendradatta, email: mardiki@yahoo.co.id

${ }^{2}$ Universitas Mahendradatta, email: ginahignasari@gmail.com
} 


\section{PENDAHULUAN}

Perkembangan teknologi berdampak besar pada pembelajaran, tentunya pada konteks pendidikan di lingkungan sekolah. Konsep pendidikan abad ke-21 telah diadaptasi dalam mengembangkan kurikulum yang dipakai saat ini. Kurikulum abad ke-21 akan mempertimbangkan teori konstruktivis sosial dalam teknologi baru untuk memungkinkan peserta didik mendapatkan kesempatan belajar maksimal serta menyiratkan praktik baru untuk memenuhi kebutuhan peserta didik (Acedo \& Hughes, 2014).

Keterampilan yang wajib dimiliki oleh peserta didik yakni keterampilan informasi, teknologi dan media, kolaborasi dan komunikasi, serta berpikir kritis dan pemecahan masalah (Arsad, Osman, $\&$ Soh, 2011). Pembelajaran di abad yang sangat canggih ini lebih memprioritaskan peserta didik aktif mencari sumber belajar untuk menambah wawasannya tentang materi yang dipelajari. Sehingga ilmu yang diperoleh akan menjadi dasar pengalaman yang kuat bagi peserta didik saat belajar. Penggunaan teknologi tepat guna dan pembelajaran aktif akan memungkinkan peserta didik untuk belajar secara bermakna dan antusias melalui berbagai kegiatan (Khlaisang \& Songkram, 2017). Oleh karena itu dalam setiap kegiatan pembelajaran diperlukan suatu gagasan yang dapat membantu pendidik untuk memberikan pemahaman dan rangsangan kepada peserta didik ketika belajar (Sadiman, 2014).

Media pembelajaran memiliki hubungan yang erat dengan kegiatan pembelajaran, karena media dapat membantu pendidik dalam menyampaikan materi pembelajaran kepada siswa untuk mencapai tujuan pembelajaran. Media pembelajaran merupakan segala sesuatu yang dapat di manfaatkan guru atau dapat membantu guru dalam menyampaikan materi pembelajaran kepada siswnya (Smaldino, Sharon E., Deborah L.L., James D.R., 2014). Media pembelajaran digunakan guru guna membantu menyampaikan materi kepada siswa, sehingga tujuan pembelajaran dapat tercapai. Media pembelajaran kemungkinan memberikan komunikasi dan akses ke informasi yang lebih menarik perhatian khususnya pada peserta didik (Pinto, Festas, \& Seixas, 2016). Pendidik merupakan tokoh utama yang bertanggung jawab dalam pendidikan, sangat penting untuk tetap mengikuti perkembangan, mengembangkan program pembelajaran dan kebijakan pendidikan tentang media pembelajaran (Pérez-Escoda, García-Ruiz, \& Aguaded, 2016).

Saat pembelajaran berlangsung pendidik menggunakan berbagai macam cara untuk menyampaikan materi agar tujuan pembelajaran tercapai, salah satunya dengan menggunakan media pembelajaran. Tujuan menggunakan media pembelajaran menurut Smaldino (2014) yakni untuk memudahkan komunikasi dan belajar. Penggunaan media pembelajaran juga bertujuan menarik perhatian peserta didik dan memperkuat konsentrasi mereka di kelas (Alghamdi \& Kingdom, 2015).

Berdasarkan beberapa pendapat para ahli dapat disimpulkan media berbasis virtual reality memberikan kesan dapat melihat keseluruhan bagian. Misalkan apabila biasanya media hanya dapat dilihat dari satu arah saja atau hanya dapat melihat dalam jangkauan media yang direkam oleh kamera, namun pada media yang berbasis virtual reality ini memungkinkan dapat melihat bagian atas, bawah, 
samping dan belakang dari media tersebut. Pengalaman melihat media berbasis virtual reality ini dapat memberikan sebuah pengalaman yang seakan nyata dan terasa seperti pada aslinya.

Pengembangan media virtual reality tata surya mengacu pada perkembangan teknologi pendidikan khususnya pada media pembelajaran. Menurut Chamberlain (2012) ketersedian teknologi dalam kegiatan pembelajaran memungkinkan peserta didik mendapatkan pengalaman belajar yang lebih melalui media pembelajaran dalam mempelajari suatu materi. Banyak faktor yang mempengaruhi peserta didik dalam belajar. Teknologi telah merubah cara belajar peserta didik (White, 2013). Peserta didik saat ini merupakan pebelajar digital (Ivanova \& Ivanova, 2009). Beberapa pernyataan tersebut menarik kesimpulan bahwa orientasi pembelajaran juga harus diubah untuk memenuhi kebutuhan peserta didik dengan karakteristik pebelajar digital (Franklin, 2015). Pembelajaran juga harus menekankan pada menciptakan kemampuan peserta didik untuk menerapkan teknologi dalam proses pembelajaran (Arsad, Osman, \& Soh, 2011).

Latar belakang penelitian dan pengembangan media pembelajaran ini didasarkan pada analisis kebutuhan siswa maupun guru terhadap media pembelajaran yang dapat membantu dalam menyampaikan materi pada muatan elajaran IPA yang relevan dengan lingkungan dengan teknologi yang sangat canggih. Berdasarkan hasil observasi yang dilakukan peneliti di SDN 4 Tuban Bali, diketahui bahwa siswa merasa bosan dengan media pembelajaran yang digunakan oleh guru. Siswa merasa media gambar (visual) tidak menarik lagi sebagai alat bantu pembelajaran. Sehingga ini berdampak pada kesuksesan akademis peserta didik. Peserta didik juga berpendapat bahwa materimateri pembelajaran yang sebelumnya mereka dapatkan dengan media yang dipakai pendidik atau guru cenderung cepat hilang.

Kegiatan pembelajaranjuga tidak selalu sejalan dengan apa yang menjadi tujuan pembelajaran. Dalam pelaksanaannya sering muncul masalah-masalah yang mengganggu proses kegiatan pembelajaran. Salah satu permasalahan yang sering muncul saat ini yaitu pendidik kurang memahami keinginan peserta didik dalam belajar. Peserta didik saat ini lebih menyukai belajar dengan memanfaatkan tab atau smartphone dari pada media pembelajaran yang lain (Tanjung \& Gultom, 2017). Peserta didik juga lebih memilih belajar dengan media yang memiliki efek tiga dimensi dan efek visual (G. Ivanova, Aliev, \& Ivanov, 2014).

Tata surya merupakan materi pembelajaran yang ada pada kelas VI sekolah dasar. Materi tata surya terdapat pada muatan Ilmu Pengetahuan Alam sesuai dengan Permendikbud Nomor 21 Tahun 2016 tentang Standar Isi Pendidikan Dasar dan Menengah. Tujuan kurikulum mencakup empat aspek kompetensi, yakni kompetensi sikap spiritual, sikap sosial, pengetahuan, dan keterampilan. Kompetensi tersebut dicapai dengan melalui proses pembelajaran.

Kompetens Inti (KI) dan Kompetensi Dasar (KD) dari materi muatan pembelajaran IPA yang ada di kelas VI sekolah dasar dijelaskan sebagai berikut. Materi tata surya termasuk kedalam salah satu kompetensi dasar yang ada pada Kompetensi Inti 3 tentang pengetahuan pada muatan pembelajaran Ilmu Pengetahuan Alam (IPA). Kompetensi Inti 3 tentang pengetahuan bertujuan yakni 
memahami pengetahuan faktual dan konseptual dengan cara mengamati, menanya, dan mencoba berdasarkan rasa ingin tahu tentang dirinya, mahkluk hidup ciptaan Tuhan dan kegiatannya, dan benda-benda yang dijumpainya di rumah, di sekolah dan di tempat bermain. Kompetensi Dasar 3.7 Menjelaskan sistem tata surya dan karakteristik anggota tata surya sesuai dengan Permendikbud Nomor 24 Tahun 2016 tentang Kompetensi Inti dan Kompetensi Dasar Muatan Pembelajaran Pada Kurikulum 2013 Pendidikan Dasar.

Tata surya merupakan materi yang mempelajari tentang benda-benda yang ada diluar angkasa. Dalam sistem tata surya menurut Soeyati (2007), Matahari sebagai pusat orbit. Matahari merupakan salah satu benda angkasa yang sangat berpengaruh di dalam sistem tata surya. Selain Matahari terdapat juga planet-planet yang ada di dalam tata surya. Soeyanti (2007) menyebutkan bahwa terdapat sembilan planet, diantaranya Merkurius, Venus, Bumi, Mars, Jupiter, Saturnus, Uranus, Neptunus dan Pluto. Kemudian pada tahun 2006 disepakati bahwa Pluto bukan termasuk planet melainkan asteroid. Planet-planet ini bergerak mengelilingi Matahari dan berotasi pada sumbunya. Rotasi merupakan gerak berputarnya planet pada sumbunya, sedangkan gerak planet yang mengelilingi Matahari disebut revolusi atau masa orbital.

Planet-planet yang ada dalam tata surya menurut Soeyanti (2007) terbagi menjadi dua yakni planet-planet dalam dan planet-planet luar. Planet-planet dalam terdiri dari Merkurius, Venus, Bumi dan Mars, sedangkan planet-planet luar meliputi planet Jupiter, Saturnus, Uranus dan Neptunus. Planet-planet dalam tata surya ini mempunyai karakteristik dan posisi masing-masing.

Uraian tersebut membawa terhadap munculnya kebutuhan akan pengembangan media pembelajaran bagi siswa sekolah dasar terhadap materi pada muatan pelajaran IPA yang disampaikan oleh guru pada saat kegiatan belajar mengajar. Selain itu, pengembangan media pembelajaran yang dibutuhkan mengikuti perkembangan zaman yang sudah memasuki zaman modern ini. Selain itu peserta didik juga lebih menyukai dan memilih belajar dengan media pembelajaran yang bersifat tiga dimensi atau efek visual yang serupa dengan yang nyata (Ivanova, Aliev, \& Ivanov, 2014).

Pengalaman nyata dan virtual dapat dibagi menjadi tiga domain; fisik, sosial, dan diri. Pengalaman fisik melibatkan pengalaman benda fisik dan lingkungan; pengalaman sosial mengacu pada pengalaman aktor sosial; dan pengalaman diri menggambarkan pengalaman yang dimiliki orang dari diri mereka sendiri (Makransky, Lilleholt, \& Aaby, 2017).

Peneliti memberikan solusi dengan pengembangkan sebuah media pembelajaran yang dapat mengatasi permasalahan-permasalahan yang sudah dipaparkan. Media pembelajaran tersebut berupa media dengan format Virtual Reality (VR), yang dapat membantu guru dalam menyampaikan materi muatan pelajaran IPA pada saat kegiatan belajar mengajar. Virtual reality merupakan teknologi yang ampuh untuk memecahkan masalah dunia nyata saat ini (Sun, Lin, \& Wang, 2010). Virtual reality (VR), atau lingkungan virtual, adalah sintesis realitas sebagai sarana untuk menciptakan cara berinteraksi antara komputer dengan manusia ( $\mathrm{Lv}, \mathrm{Li}, \& \mathrm{Li}, 2017)$. virtual reality atau (VR) adalah teknologi yang mengakibatkan penggunanya mampu berinteraksi pada satu area yang diimitasikan 
computer (Mihelj, M., Domen N., 2014). Virtual reality adalah simulasi lingkungan oleh komputer yang bisa mensimulasikan kehadiran fisik secara nyata atau dunia yang dibayangkan (Motamedi, Wang, Yabuki, Fukuda, \& Michikawa, 2017). Berdasarkan latar belakang yang telah dipaparkan, peneliti tertarik melakukan penelitian untuk mengembangkan sebuah produk yang dapat memberikan alternarif bagi guru dalam menggunakan media pembelajaran dan juga didukung inovasi baru dalam dunia teknologi. Peneliti merasa penelitian ini penting untuk dilaksanakan serta menuangkannya ke dalam penelitian ini.

\section{METODE}

Model penelitian yang digunakan pada penelitian ini ialah model 4D (Thiagarajan, S., Semmel, D., Semmel, M.I., 1974). Model 4D ini terdiri dari empat tahapan, yakni define (pendefinisian), design (perancangan), develop (pengembangan), dan disseminate (penyebaran). Tahapan penelitian ini dilakukan sampai tahapan develop (pengembangan) sehingga model penelitian dan pengembangan telah di modifikasi. Adapun tahapan-tahapannya sebagai berikut.

Tahap define merupakan merupakan tahapan untuk mendefinisikan dan menetapkan kebutuhan pembelajaran dengan cara menganalisis tujuan serta batasan terhadap materi pada matan pelajaran IPA kelas VI sekolah dasar. Tahap ini juga mempunyai beberapa tahapan yakni, front-end analysis (analisis menyeluruh), learner analysis (analisis peserta didik), task analysis (analisis tugas), concept analysis (analisis konsep) dan specifying instructional objectives (tujuan pembelajaran).

Front-end analysis (analisis menyeluruh) bertujuan untuk mengetahui tujuan dari kegiatan pembelajaran, sehingga dibutuhkan pengembangan media pembelajaran. Tujuan yang didapatkan oleh peneliti berdasarkan kegiatan analisis kurikulum dan analisis lapangan secara keseluruhan dengan melakukan wawancara serta pengamatan selama proses pembelajaran tentang penggunaan media pembelajaran. Learner analysis (analisis peserta didik) bertujuan untuk mengetahui karakteristik peserta didik agar media pembelajaran yang nantinya akan dikembangkan dapat disesuaikan dengan konsep atau materi. Karakteristik peserta didik yang dianalisis meliputi perkembangan psikologi peserta didik dan kemampuan berpikir peserta didik. Task analysis (analisis tugas) bertujuan untuk mengidentifikasi jenis tugas yang akan diberikan kepada peserta didik, mencapai kompetensi utama yang wajib dikuasai setelah memanfaatkan media pembelajaran yang dikembangkan sesuai dengan kompetensi dasar dan indikator pencapaian pembelajaran.

Selanjutnya Concept analysis (analisis konsep) bertujuan untuk memenuhi prinsip dalam membangun konsep atas materi-materi yang digunakan sebagai sarana untuk pencapaian kompetensi inti dan kompetensi dasar. Dalam mendukung analisis konsep ini, analisis yang dilakukan yakni: analisis kompetensi inti dan kompetensi dasar; analisis sumber belajar untuk mengumpulkan dan mengidentifikasi sumber mana yang mendukung penyusunan konsep; analisis konsep yakni identifikasi konsep-konsep utama yang akan disampaikan dengan media pembelajaran yang dikembangkan dan menyusun secara sistematis dengan merinci konsep-konsep yang relevan. 
Specifying instructional objectives (tujuan pembelajaran) bertujuan untuk merangkum analisis konsep dan analisis tugas sebagai acuan untuk merancang dan menyusun perangkat pembalajaran yang kemudian diintegrasikan kedalam materi perangkat pembelajaran.

Tahap design bertujuan untuk merancang prototype media virtual reality. Model 4D pada tahap ini mempunyai empat langkah, berikut langkah-langkah tahap design: Constructing CriterionReferenced Test (Penyusunan Tes Acuan Patokan), Media Selection (Pemilihan Media), Format Selection (Pemilihan Format), dan Initial Design (Merancang Awal).

Constructing Criterion-Referenced Test (Penyusunan Tes Acuan Patokan) merupakan penghubung antara tahap pendefinisian dan perancangan. Tes acuan patokan dibuat dengan mendasar pada kekhususan tujuan pembelajaran dan analisis terhadap karakteristik peserta didik yang nantinya dijadikan dasar dalam pembuatan kisi-kisi retensi peserta didik. Media Selection (Pemilihan Media) media yang nantinya akan dikembangkan berupa media audio-visual yang akan digunakan dalam kegiatan pembelajaran. Pengembangan media ini berdasarkan hasil analisis konsep, analisis materi dan karakteristik peserta didik. Format Selection (Pemilihan Format) bertujuan untuk menentukan format dalam mendesain isi pembelajaran dalam media pembelajaran yang dikembangkan. Media pembelajaran dikembangkan dengan format virtual reality. Initial Design (Merancang Awal) bertujuan untuk merancang media pembelajaran berupa virtual reality tata surya. Pada tahap merancang awal terdapat dua tahapan yakni; pertama pembuatan story board dan tahap yang kedua yakni validasi oleh dosen pembimbing.

Tahap develop bertujuan untuk menghasilkan sebuah produk yang akan dikembangkan. Berikut tahapan pengembangan yang dilalui pada tahap ini: pertama expert appraisal (penilaian para ahli) dengan proses revisi. Tahapan yang dilakukan pada tahap ini bertujuan untuk menghasilkan final draft (draft akhir). Final draft (draft akhir) yang dihasilkan telah melalui tahapan perbaikan dari pra ahli sesuai dengan bidangnya berdasarkan tanggapan, masukan, saran, kritik pada saat uji coba produk.

Tahap ini bertujuan untuk menguji kevalidan produk yang dikembangkan. Tahap validasi ahli yang dilakukan akan menghasilkan data berupa masukan dan kritikan dari para validator. Tahapan yang dilakukan yakni berdiskusi dan menyerahkan produk berupa media pembelajaran yang dikembangkan sesuai dengan acuan desain media, materi dan penerapan lapangan kepada para ahli (validator). Hasil yang diperoleh saat validasi dari para validator selanjutnya dianalisis sebagai acuan untuk melaksanakan revisi produk yang telah dikembangkan. Berikut analisis validitas data pada uji validasi.

\section{Keterangan:}

$$
\begin{aligned}
& \begin{aligned}
\boldsymbol{V} \cdot \boldsymbol{a h}=\frac{\boldsymbol{T S} \boldsymbol{e}}{\boldsymbol{S} \cdot \boldsymbol{m a x}} \times \mathbf{1 0 0} \% & \text { V.ah }=\text { Skor validitas ahli } \\
\quad \text { TSe } & =\text { Total skor empirik yang dihasilkan }
\end{aligned} \\
& \text { S.max }=\text { Skor yang diharapkan }
\end{aligned}
$$


Nilai presentase kevalidan diinterpretasikan sesuai dengan kriteria pada table berikut ini.

Tabel 1 Kriteria Kevalidan Media yang dikembangkan

\begin{tabular}{cc}
\hline Kriteria & Tingkat Validitas \\
\hline $\mathbf{8 0 , 0 1 \%}-\mathbf{1 0 0 \%}$ & Sangat valid \\
\hline $\mathbf{6 0 , 0 1 \%}-\mathbf{8 0 , 0 0 \%}$ & Valid \\
\hline $\mathbf{4 0 , 0 1 \%}-\mathbf{6 0 , 0 0 \%}$ & Kurang valid \\
\hline $\mathbf{2 0 , 0 1 \%}-\mathbf{4 0 , 0 0 \%}$ & Tidak valid \\
\hline $\mathbf{0 0 , 0 0 \%}-\mathbf{2 0 , 0 0 \%}$ & Sangat tidak valid \\
\hline
\end{tabular}

Merujuk pada kriteria validasi pada tabel di atas, media dapat digunakan jika dinyatakan valid atau sangat valid dengan memperoleh skor $60,01-100 \%$. Subjek pada penelitian ini terdiri atas ahli media, ahli materi, dan ahli penrapan lapangan sebagai validator media pembelajaran yang dikembangkan. Validasi media pembelajaran dilakukan oleh satu orang dosen Universitas Mahendradatta yang berkompeten pada bidang media pembelajaran, dengan kualifikasi pendidikan minimal S2 (Magister) dan berpengalaman dibidangnya minimal 5 tahun. Lembar validasi media pembelajaran bertujuan untuk mendapatkan data berupa penilaian, pendapat, saran serta masukan terhadap kesesuaian dan kelayakan.

Validasi media pembelajaran dilakukan oleh satu orang dosen Universitas Mahendrdatta dengan kualifikasi pendidikan minimal S2 (Magister) dan berpengalaman dibidangnya minimal 5 tahun. Lembar validasai media oleh ahli materi bertujuan untuk mendapatkan data berupa penilaian, pendapat, saran serta masukan terhadap keteapatan serta kesesuaian dengan kompetensi dasar dan kebenaran materi yang dikembangkan dalam media ini. Validasi media pembelajaran dilakukan oleh satu orang pendidik dengan kualifikasi pendidikan minimal S1 (Sarjana) dan berpengalaman dibidangnya minimal 5 tahun. Lembar validasai media oleh ahli penerapan lapangan bertujuan untuk mendapatkan data berupa penilaian, pendapat, saran serta masukan terhadap keteapatan serta kesesuaian dengan kurikulum dan kesesuaian terhadap proses pembelajaran yang dikembangkan dalam media ini.

Data yang telah dikumpulkan selanjutnya dianalisis menggunakan analisis data desriptif. Analisis ini meliputi analisis data deskriptif kualitatif serta analisis data deskriptif kuantitatif. Teknik analisis deskriptif kualitatif digunakan bertujuan untuk menganalisa data berupa catatan, saran, atau komentar berdasarkan hasil yang diperoleh dari uji validasi dan uji coba media pembelajaran. Data yang diperoleh digunakan sebagai masukan dan dasar pada saat merevisi produk media pembelajaran yang dikembangkan. Analisis data deskriptif kualitatif menggunakan model Miles and Huberman. Adapun tahapan sebagai berikut; reduksi data (data reduction), penyajian data 
(data display), dan penarikan kesimpulan serta verifikasi data (conclusion drawing/ verification). Teknik analisis data deskriptif kuantitatif digunakan untuk tujuan menganalisis data yang berupa skor (angka) dari hasil validasi serta hasil belajar peserta didik. Terdapat empat analisis deskriptif kuantitatif yaitu analisis kevalidan dan analisis keefektifan.

Keefektifan media dinyatakan dari interpretasi analisis tes hasil belajar peserta didik. Analisis ini dilakukan berdasarkan tingkat persentase ketuntasan belajar peserta didik dan selisih rata-rata antara tes hasil belajar seluruh peserta didik. Nilai ketuntasan peserta didik berpedoman pada nilai Kriteria Ketuntasan Minimal (KKM) yang ditetapkan oleh sekolah, yakni 70. Peserta didik dapat dikatakan tuntas jika mencapai nilai KKM. Media dapat dinyatakan efektif apabila persentase ketuntasan pada tes akhir hasil belajar peserta didik mencapai $80 \%$ dari keseluruhan peserta didik.

\section{HASIL PENELITIAN}

Pengembangan yang dilakukan menghasilkan produk berupa media pembelajaran berbasis virtual reality. Media pembelajaran ini disajikan dalam bentuk aplikasi android yang dapat dipasang dan dibuka pada smartphone yang berbasis android. Media ini menyajikan materi tata surya pembelajaran Ilmu Pengetahuan Alam. Materi yang disajikan terfokus pada matahari dan planetplanet. Materi ini dikemas ke dalam bentuk virtual reality yang dapat memberikan kesan pada pengguna media ini seolah-olah dapat melihat langsung objek seperti matahari dan planet-planet yang berada diluar angkasa. Untuk melihat objek-objek tersebut dapat dilakukan dengan VR Box. Aplikasi ini berisi beberapa menu yang dapat dipilih oleh penggunanya.

Validasi ahli media pada media yang dikembangkan terdiri dari 21 aspek. Berikut hasil validasi oleh ahli media. Berdasarkan dari persentase hasil validasi yang dilakukan oleh ahli media pembelajaran terhadap media yang dikembangkan, memperoleh skor persentase yakni sebesar $85 \%$. Hasil persentase dari validasi ahli media pembelajaran dapat diambil kesimpulan bahwa media yang dikembangkan dapat digunakan karena hasil persentase memperoleh skor melebihi skor minimal yakni 60,01\% (Akbar, 2013). Revisi dilakukan pengembang agar media pembelajaran yang dikembangkan dapat menjadi lebih baik. Revisi media diantaranya dengan melakukan perekaman ulang suara narator dalam menjelaskan materi dan menambaha teks informasi untuk setiap objek.

Validasi ahli materi pada media yang dikembangkan terdiri dari 5 aspek. Berdasarkan dari persentase hasil validasi yang dilakukan oleh ahli materi pembelajaran terhadap media yang dikembangkan, memperoleh skor persentase yakni sebesar $82 \%$. Hasil persentase dari validasi ahli materi pembelajaran dapat diambil kesimpulan bahwa media yang dikembangkan dapat digunakan karena hasil persentase memperoleh skor melebihi skor minimal yakni 60,01\% (Akbar, 2013). Revisi dilakukan pengembang agar media pembelajaran yang dikembangkan dapat menjadi lebih baik. Hasil revisi dapat dilihat pada tabel berikut. 
Tabel Revisi Media Berdasarkan Ahli Materi

\begin{tabular}{|c|c|}
\hline Sebelum Revisi & Sesudah Revisi \\
\hline Belum ada tombol pause di VR & Sudah dibuatkan tombol pause \\
\hline Belum ada tombol exit atau keluar di VR & Sudah dibuatkan tombol exit atau keluar \\
\hline $\begin{array}{l}\text { Tambahkan tata surya mini di depan } \\
\text { astronot }\end{array}$ & $\begin{array}{l}\text { Sudah dibuatkan tata surya di depan astronot saat } \\
\text { menjelaskan tentang tata surya }\end{array}$ \\
\hline $\begin{array}{l}\text { Tambahkan narasi agar lebih interakitf } \\
\text { setiap objek }\end{array}$ & $\begin{array}{l}\text { Sudah ditambahkan narasi yang mengandung } \\
\text { unsur interaktif }\end{array}$ \\
\hline $\begin{array}{l}\text { Kata lewati pada setiap teks diganti dengan } \\
\text { kata lanjutkan perjalanan }\end{array}$ & Sudah diganti dengan kata lanjutkan perjalanan \\
\hline $\begin{array}{l}\text { Pada latihan soal, skor diganti menjadi } \\
\text { rentang } 0-100\end{array}$ & Skor sudah diganti dengan rentang $0-100$ \\
\hline $\begin{array}{l}\text { Gambar planet Bumi dan logo UM } \\
\text { disamakan ukurannya }\end{array}$ & $\begin{array}{l}\text { Sudah disamakan ukuran antara planet Bumi dan } \\
\text { logo UM }\end{array}$ \\
\hline $\begin{array}{l}\text { Tambahkan petunjuk penggunaan VR } \\
\text { dengan memfokuskan titik agar dapat } \\
\text { bekerja }\end{array}$ & $\begin{array}{l}\text { Pada petunjuk penggunaan sudah diberi petunjuk } \\
\text { agar memfokuskan pada titik agar VR dapat } \\
\text { dijalankan }\end{array}$ \\
\hline $\begin{array}{l}\text { Tombol home kurang lengkap dan harus } \\
\text { muncul disetiap menu agar lebih mudah } \\
\text { untuk memilih menu yang ingin dituju }\end{array}$ & $\begin{array}{l}\text { Sudah dilakukan perbaikan dengan menambah } \\
\text { tombol home agar dapat memudahkan pengguna } \\
\text { untuk memilih menu yang ingin dituju }\end{array}$ \\
\hline $\begin{array}{l}\text { Petunjuk penggunaan media kurang sama } \\
\text { dengan kegiatan pembelajaran }\end{array}$ & $\begin{array}{l}\text { Petunjuk penggunaan media disamakan dengan } \\
\text { kegiatan pembelajaran }\end{array}$ \\
\hline
\end{tabular}

Validasi ahli penerapan lapangan terhadap media pembelajaran yang dikembangkan terdiri dari 3 aspek. Berdasarkan dari persentase hasil validasi yang dilakukan oleh ahli penerapan lapangan terhadap media yang dikembangkan, memperoleh skor persentase yakni sebesar $89 \%$. Hasil persentase dari validasi ahli penerapan lapangan dapat diambil kesimpulan bahwa media yang dikembangkan dapat digunakan karena hasil persentase memperoleh skor melebihi skor minimal yakni 60,01\% (Akbar, 2013).

Hasil validasi oleh ahli penerapan lapangan dapat dilihat pada tabel berikut.

Tabel Hasil Validasi Ahli Penerapan Lapangan

\begin{tabular}{clcc}
\hline No. & \multicolumn{1}{c}{ Aspek Yang Dinilai } & Rata-rata (\%) & Keterangan \\
\hline $\mathbf{1}$ & Kebenaran isi materi & $100 \%$ & Sangat Valid \\
\hline $\mathbf{2}$ & Kedalaman materi sesuai karakteristik sekolah dasar & $91,5 \%$ & Sangat Valid \\
\hline $\mathbf{3}$ & Kejelasan materi & $75 \%$ & Valid \\
\hline & Skor Rata-rata & $\mathbf{8 9 \%}$ & Sangat Valid \\
\hline
\end{tabular}


Ahli penerapan lapangan sudah mengganggap media yang dikembangkan sudah dapat digunakan pada peserta didik kelas VI sekolah dasar. Sehingga tidak ada revisi yang dilakukan pengembang pada hasil validasi ahli penerapan lapangan.

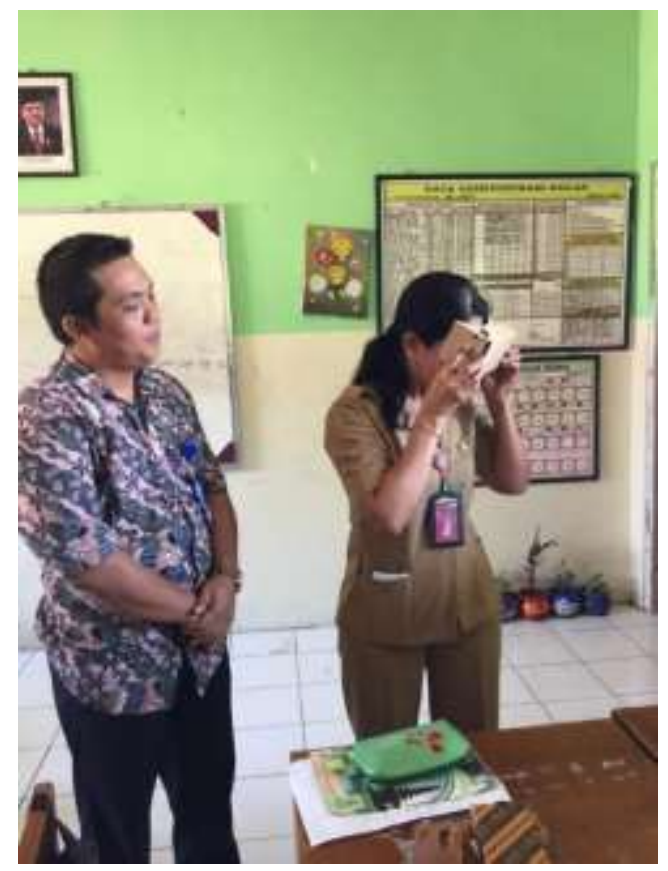

\section{Gambar Uji Validitas Bersama Ahli Penerapan Lapangan}

Hasil validasi media pembelajaran yang dikembangkan dapat dikatakan layak untuk digunakan karena telah memenuhi nilai ambang batas / persentase bagaimana sebuah produk dapat dikatakan layak. Hasil validasi dari ahli media yakni memperoleh skor persentase yakni sebesar $85 \%$. Hasil validasi dari ahli materi yakni memperoleh skor persentase yakni sebesar $82 \%$. Sedangkan hasil validasi ahli penerapan lapangan yakni memperoleh skor persentase yakni sebesar 89\%. Nilai persentase dari ketiga ahli melebihi skor minimal yakni $60,01 \%$ sehingga dapat disimpulkan bahwa media pembelajaran yang dikembangkan sudah dinyatakan layak digunakan.

Hasil penelitian pada uji coba lapangan teradap siswa menyimpulkan bahwa hasil beajar peserta didik terhadap pemahaman konsep telah memenuhi KKM yang telah ditetapkan dengan jumlah persentase keseluruhan yakni mencapai $88 \%$ dari jumlah siswa. Hasil ini menyatakan bahwa media yang dikembangkan saat kegiatan pembelajaran telah mengakomodasi peserta didik dalam belajar dan membantu peserta didik terhadap pemahaman konsep materi tata surya yang lebih baik serta melalui media pembelajaran yang dikembangkan dapat memberikan kesan kepada peserta didik seperti berada pada lingkungan sebenarnya sehingga peserta didik dapat melihat langsung bentuk konsep yang diajarkan Pendidik pada saat kegiatan pembelajaran.

\section{PEMBAHASAN}

Penggunaan media yang berbasis virtual reality ini bertujuan untuk membantu guru dalam menjelaskan konsep matahari dan planet-planet pada muatan pelajaran IPA agar lebih paham karena 
sifat dari media ini dapat memberikan bentuk konkret dari matahari dan planet yang selama ini dipelajari peserta didik melalui gambar.

Pengembangan yang telah dilakukan oleh peneliti menghasilkan sebuah produk dengan nama Media Virtual Reality. Media yang disajikan dalam bentuk aplikasi berbasis android yang hanya dapat digunakan pada smartphone yang berbasis android dan juga sudah memiliki layar gyroschop. Media ini hanya dapat digunakan dengan bantuan kacamata Virtual. Materi dalam media ini merupakan materi tata surya yang terdapat pada sekolah dasar. Materi tata surya disesuaikan dengan kompetensi dasar 3.7 Menjelaskan sistem tata surya dan karakteristik anggota tata surya. Terdapat beberapa submateri dalam materi tata surya, akan tetapi peneliti memfokuskan pada konsep matahari dan planet-planet anggota tata surya.

Media pembelajaran tersebut berupa media dengan format Virtual Reality (VR), yang dapat membantu pendidik untuk menjelaskan materi tata surya pada saat kegiatan pembalajaran. Virtual reality mengacu pada penggunaan simulasi interaktif untuk pengguna dengan kesempatan untuk terlibat dalam lingkungan yang mungkin tampak dan terasa serupa dengan benda dan peristiwa dunia nyata dan itu mungkin menimbulkan perasaan hadir di dunia maya (Ghali et al., 2012).

Virtual reality juga merupakan salah satu teknologi yang efektif untuk memecahkan masalah dunia nyata saat ini. Untuk tujuan pendidikan pada umumnya, virtual reality telah banyak diusulkan sebagai terobosan teknologi yang signifikan yang memiliki potensi besar untuk memfasilitasi kegiatan pembelajaran (Sun, Lin, \& Wang, 2010).

Media yang dikembangkan ini dilengkapi dengan buku petunjuk penggunaan bagi Pendidik yang akan menggunakan media. Buku petunjuk penggunaan tersebut berisi sampul buku, pendahuluan, daftar isi, identitas media pembelajaran yang dikembangkan, pedoman penggunaan media pembelajaran virtual reality, pemeliharaan dan perawatan media pembelajaran, daftar rujukan serta sampul belakang buku. Media yang dikembangkan ini dalam penggunaannya tidak terlepas dari kacamat virtual. Kacamata virtual ini nantinya berperan sebagai tempat menyimpan smartphone yang akan menampilkan virtulisasi dari materi dan konsep tata surya.

Media ini merupakan media yang dapat menvirtualisasikan sebuah objek nyata. Media yang dikembangkan ini sangat membantu Pendidik dalam menyampikan konsep yang sulit untuk dihadirkan langsung pada saat kegiatan pembelajaran dan juga materi yang bersifat abstrak, salah satu materinya yakni tentang tata surya. Hal ini sesuai dengan apa yang menjadi manfaat dari penggunaan media pembelajaran dalam kegiatan pembelajaran yakni dapat memanipulasi keadaaan, peristiwa atau objek tertentu (Sanjaya, 2012). Dibandingkan dengan buku teks dan ceramah, lingkungan belajar dengan virtualisasi komputer memiliki kelebihan sehingga peserta didik dapat secara sistematis mengeksplorasi situasi hipotetis, berinteraksi dengan versi proses atau sistem yang disederhanakan, mengubah skala waktu kejadian, dan melaksanakan tugas dan memecahkan masalah di lingkungan yang realistis (Rutten, Van Joolingen, \& Van Der Veen, 2012).

Media yang dikembangkan sudah dinyatakan valid untuk digunakan dalam kegiatan 
pembelajaran. Berdasarkan hasil validasi dari ahli media diperoleh persentase sebesar $85 \%$ dengan kriteria sangat valid. Hasil validasi dari ahli materi diperoleh persentase sebesar $82 \%$ dengan kriteria sangat valid. Hasil validasi dari ahli penerapan lapangan diperoleh persentase sebesar $89 \%$ dengan kriteria sangat valid. Berdasarkan hasil validasi dari ahli media, materi dan penerapan lapangan dapat disimpulkan bahwa media yang dikembangkan telah memenuhi kriteria untuk dapat digunakan dalam kegiatan pembelajaran karena mendapatkan hasil melebihi nilai 60,00\% (Akbar,2013). Adapun saran-saran yang diberikan validator digunakan untuk menyempurnakan media yang dikembangkan agar mendapatkan sebuah produk yang lebih baik.

Penyampaian sebuah materi atau konsep dalam bentuk audio dan visual dapat mempermudah peserta didik mempelajari konsep dan meningkatkan pemahaman serta akan lebih mudah diingat. Media ini dapat dimanfaatkan guru untuk menyampaikan materi muatan pelajaran IPA karena sudah dinyatakan valid atau layak oleh beberapa ahli yang menvalidasi. Untuk tujuan pendidikan pada umumnya, virtual reality telah banyak diusulkan sebagai terobosan teknologi yang signifikan yang memiliki potensi besar untuk memfasilitasi pembelajaran. Salah satu manfaat menggunakan virtual reality yakni berpotensi mendorong kegiatan belajar siswa (Chou, 2017). Media virtual reality selain mengandung unsur visual juga mengandung unsur audio. Virtual reality menawarkan kesempatan kepada orang untuk berinteraksi dengan cara yang menyampaikan rasa kehadiran yang kurang di media lain (González, Santos, Vargas, Martín-Gutiérrez, \& Orihuela, 2013).

Media yang digunakan dalam kegiatan pembelajaran dapat membantu peserta didik dalam memahami dan mengingat materi pembelajaran konsep tata surya. Hal tersebut sejalan dengan apa yang diutarakan Piaget (1969) bahwa pada usia 7-11 tahun peserta didik masih dalam rentang fase operasional konret karena aktivitas mental anak terfokus pada objek-objek sehingga dengan bantuan media yang dikembangkan ini dapat membuat peserta didik lebih paham dan membantu daya ingat terhadap materi terutama materi tata surya. Media ini juga dapat meningkatkan retensi peserta didik karena media yang dikembangkan ini terdapat unsur visual untuk penglihatan serta audio untuk pendengaran. Hal ini sejalan dengan apa yang digagas oleh Daryanto (2016) yang menjelaskan bahwa tingkat retensi peserta didik terhadap materi pembelajaran dapat meningkat secara signifikan jika proses pemerolehan informasi awalnya lebih besar melalui indra pendengaran dan indra penglihatan.

Uji coba lapangan teradap siswa menyimpulkan bahwa hasil beajar peserta didik terhadap pemahaman konsep telah memenuhi KKM yang telah ditetapkan dengan jumlah persentase keseluruhan yakni mencapai $88 \%$ dari jumlah siswa. Hasil ini menyatakan bahwa media yang dikembangkan saat kegiatan pembelajaran telah mengakomodasi peserta didik dalam belajar dan membantu peserta didik terhadap pemahaman konsep materi tata surya yang lebih baik serta melalui media pembelajaran yang dikembangkan dapat memberikan kesan kepada peserta didik seperti berada pada lingkungan sebenarnya sehingga peserta didik dapat melihat langsung bentuk konsep yang diajarkan Pendidik pada saat kegiatan pembelajaran. 


\section{KESIMPULAN}

Media pembelajaran berbasis virtual reality ini dapat dimanfaatkan oleh guru dalam menyampaikan materi muatan pelajaran IPA dalam kegiatan belajar mengajar karena media yang dikembangkan ini sudah mendapatkan penilaian yang sangat layak untuk digunakan dari penilaian para ahli. Media yang dikembangkan ini juga terdapat unsur visual untuk penglihatan serta audio untuk pendengaran. Media pembelejaran yang dikembangkan sudah dinyatakan layak digunakan karena telah melalui tahap uji validitas dan uji coba lapangan pada siswa. Pada tahap validitas, media pembelajaran yang dikembangkan memperoleh nilai di atas standar sehingga sangat direkomendasai untuk digunakan dalam kegitaan pembelajaran. Sedangkan pada tahap uji lapangan terhadap siswa, media embelajaran yang dikembangkan telah membantu siswa mendapatkan nilai yang telah memenuhi KKM yang ditentukan oleh guru. Kelebihan media pembelajaran berbasis virtual reality yang dikembangkan antara lain sebagai berikut. Media pembelajaran yang dikembangkan ini disajikan dalam bentuk virtual reality sehingga dapat dilihat langsung sehingga siswa pada saat kegiatan belajar mengajar tidak membayangkan bentuk akan tetapi dapat langsung melihat bentuknya. Media pembelajaran berbasis virtual reality ini mempunyai tampilan yang sangat menarik dan merupakan aplikasi terbaru dalam dunia teknologi. Media pembelajaran berbasis virtual reality ini mempunyai tingkat validitas yang sangat tinggi dan memenuhi syarat untuk dipergunakan pada saat kegiatan pembelajaran pada muatan pelajaran IPA. Tingkat validitas ini diperoleh dari hasil uji vailiditas beberapa ahli yakni ahli media pembelajaran, ahli materi pembelajaran dan ahli penerapan lapangan.

\section{DAFTAR PUSTAKA}

Acedo, C., \& Hughes, C. 2014. Principles for learning and competences in the 21st-century curriculum. Prospects, 44(4), 503-525. DOI: 10.1007/s11125-014-9330-1

Akbar, S. 2013. Instrumen Perangkat Pembelajaran. Bandung: PT Remaja Rosdakarya.

Alghamdi, A., \& Kingdom, U. 2015. An investigation of saudi teachers 'attitudes towards iwbs and their use for teaching and learning in yanbu, 8(6), 539-554.

Arsad, N. M., Osman, K., \& Soh, T. M. T. 2011. Instrument development for 21 st century skills in Biology. Procedia - Social and Behavioral Sciences, 15, 1470-1474. DOI: 10.1016/j.sbspro.2011.03.312

Chamberlain. 2012. Inquiry and Scientific Literacy. (This report is available on-line at http://www.sagepub.com/upmdata/24393_chamberlain_chapter1.pdf).

Chou, C. C. 2017. An analysis of the 3D video and interactive response approach effects on the science remedial teaching for fourth grade underachieving students. Eurasia Journal of Mathematics, Science and Technology Education, 13(4), 1059-1073. DOI: 10.12973/eurasia.2017.00658a

Daryanto. 2016. Media Pembelajaran. Yogyakarta: Gava Media. 
Franklin, T. J. 2015. Embracing the Future: Empowering the 21st Century Educator. Procedia Social and Behavioral Sciences, 176, 1089-1096. DOI: 10.1016/j.sbspro.2015.01.584

Ghali, N. I., Soluiman, O., El-Bendary, N., Nassef, T. M., Ahmed, S. A., Elbarawy, Y. M., \& Hassanien, A. E. 2012. Virtual Reality Technology for Blind and Visual Impaired People: Reviews and Recent Advances. Intelligent Systems Reference Library, 26, 363-385. DOI: 10.1007/978-3-642-23363-0_15

González, M. M. A., Santos, B. S. N., Vargas, A. R., Martín-Gutiérrez, J., \& Orihuela, A. R. 2013. Virtual worlds. Opportunities and challenges in the 21 stcentury. Procedia Computer Science, 25, 330-337. DOI: 10.1016/j.procs.2013.11.039

Ivanova, A., \& Ivanova, G. 2009. Net-Generation Learning Style, a Challenge for Higher Education. Proceedings of the International Conference on Computer Systems and Technologies and Workshop for PhD Students in Computing, 1-6. DOI: 10.1145/1731740.1731818

Ivanova, G., Aliev, Y., \& Ivanov, A. 2014. Augmented Reality Textbook for Future Blended Education. Proceedings of the International Conference on E-Learning, 14, 130-136.

Khlaisang, J., \& Songkram, N. 2017. Designing a Virtual Learning Environment System for Teaching Twenty-First Century Skills to Higher Education Students in ASEAN. Technology, Knowledge and Learning, 1-23. DOI: 10.1007/s10758-017-9310-7

Lv, Z., Li, X., \& Li, W. 2017. Virtual reality geographical interactive scene semantics research for immersive geography learning. Neurocomputing, 254, 1339-1351. DOI:

10.1016/j.neucom.2016.07.078

Makransky, G., Lilleholt, L., \& Aaby, A. 2017. Development and validation of the Multimodal Presence Scale for virtual reality environments: A confirmatory factor analysis and item response theory approach. Computers in Human Behavior, 72, 276-285. DOI: 10.1016/j.chb.2017.02.066

Mihelj, M., Domen N., \& S. B. 2014. Virtual Reality Technology and Applications. London: Springer Science \& Business Media.

Motamedi, A., Wang, Z., Yabuki, N., Fukuda, T., \& Michikawa, T. 2017. Signage visibility analysis and optimization system using BIM-enabled virtual reality (VR) environments. Advanced Engineering Informatics, 32, 248-262. DOI: 10.1016/j.aei.2017.03.005

Pérez-Escoda, A., García-Ruiz, R., \& Aguaded, I. 2016. International dimensions of media literacy in a connected world. Applied Technologies and Innovations, 1212(22), 95-106. DOI: 10.15208/ati.2016.08

Permendikbud Nomor 20 Tahun 206 tentang Standar Kompetensi Lulusan pada Jenjang Pendidikan Dasar. 2016. Jakarta.

Permendikbud Nomor 21 Tahun 2016 tentang Standar Isi Pendidikan Dasar dan Menengah. 2016. Jakarta.

Permendikbud Nomor 24 Tahun 2016 tentang Kompetensi Inti dan Kompetensi Dasar. 2016. Jakarta.

Pinto, A., Festas, M. I., \& Seixas, A. M. 2016. Digital media and the challenges for media education. 12(2), 43-53. 
Rutten, N., Van Joolingen, W. R., \& Van Der Veen, J. T. 2012. The learning effects of computer simulations in science education. Computers and Education, 58(1), 136-153. DOI: 10.1016/j.compedu.2011.07.017

Sadiman, A. S. 2014. Media Pendidikan, Pengertian, Pengembangan dan Pemanfaatannya. Jakarta: PT Raja Grafindo Persada.

Smaldino, Sharon E., Deborah L.L., James D.R. 2014. Instructional Technology and Media for Learning (Sembilan). Jakarta: Kencana Prenada Media Group.

Sun, K. T., Lin, C. L., \& Wang, S. M. 2010. A 3-D Virtual Reality Model of The Sun and the Moon For E-Learning At Elementary Schools. International Journal of Science and Mathematics Education, 8(4), 689-710. DOI: 10.1007/s10763-009-9181-z

Tanjung, F. Z., \& Gultom, U. A. 2017. Reading habits in digital era: a research on the students in borneo university, 20(2), 147-157.

Thiagarajan, S., Semmel, D., Semmel, M.I. 1974. Instructional Development for Training Teachers of Exceptional Children. Indiana: Indiana University.

White, G. K. 2013. Digital fluency: skills necessary for learning in the digital age. Australian Council of Educational Research, 1-12. Retrieved from http://research.acer.edu.au/digital_learning 